\title{
Synthesis and Characterization of Benzothiazol Derivative as a Corrosion Inhibitor for Carbon Steel in Seawater
}

\author{
Abdulkareem Mohammed Ali Al-Sammarraie*, Khulood Abid Al-Saade, \\ Mohammed H. A. Al-Amery \\ Department of Chemistry, College of Science, Baghdad University, Baghdad, Iraq \\ Email: samuraee2000@hotmail.com
}

Received 20 January 2015; accepted 27 July 2015; published 30 July 2015

Copyright (C) 2015 by authors and Scientific Research Publishing Inc.

This work is licensed under the Creative Commons Attribution International License (CC BY). http://creativecommons.org/licenses/by/4.0/

(c) (i) Open Access

\begin{abstract}
2(Benzo[d]thiazol-2-ylamino)-2-(2-hydroxy-phenyl) acetonitrile derivative was prepared and characterized using thin liquid chromatography, FTIR, ${ }^{1} \mathrm{H}$ NMR and ${ }^{13} \mathrm{C}$ NMR. The corrosion protectiveness, kinetics, and thermodynamics of the prepared derivative as inhibitor in artificial sea water/carbon steel (CK45) system were studied. Three concentrations of the prepared inhibitor were examined, namely, 10, 100, and $1000 \mathrm{ppm}$; protection efficiencies of $23 \%$ to $73 \%$ were recorded. It was found that the experimental data obtained from polarization reading could be fitted by Langmuir isotherm and Frumkin's isotherm; the best fit adsorption isotherm was the Frumkin adsorption isotherm. The small negative value of $\Delta G_{a d s}$ indicates the spontaneity of a physical adsorption process and the stability of the adsorbed layer on the carbon steel surface. Analysis of the temperature dependence of inhibition efficiency as well as comparison of corrosion activation in absence and in presence of the inhibitors gives some insight into the possible inhibition mechanism.
\end{abstract}

\section{Keywords}

Corrosion Inhibition, Benzothiazole Derivative, Corrosion Kinetics

\section{Introduction}

Seawater is one of the most corroded and most abundant naturally occurring electrolytes, covering about $70 \%$ of the earth's surface. The corrosively of the seawater is reflected by the fact that most of the common structural metals and alloys are attacked by this liquid or its surrounding [1]. Carbon steel is the most versatile, least ex-

*Corresponding author.

How to cite this paper: Al-Sammarraie, A.M.A., Al-Saade, K.A. and Al-Amery, M.H.A. (2015) Synthesis and Characterization of Benzothiazol Derivative as a Corrosion Inhibitor for Carbon Steel in Seawater. Materials Sciences and Applications, 6, 681-693. http://dx.doi.org/10.4236/msa.2015.67070 
pensive and widely used engineering material which has found extensive application in various industries [2]. It is used in large tonnages in marine applications, nuclear power and fossil fuel power plant, transportation, chemical processing, petroleum production and refining, pipelines, mining, construction as well as metal processing equipment. However, the corrosion resistance of carbon steel is relatively limited. This causes many corrosion problems to be arising in the related industries [3]-[5]. Using inhibitors is an important method for protecting materials against corrosion [6]-[8]. Various types of organic inhibitors have been published [9]. The molecules most often used as corrosion inhibitors are nitrogen, sulfur, oxygen and phosphorus compound [10]-[13]. Nitrogen and sulfur as constituent atoms were studied as corrosion inhibitor in HCl medium [14] [15].

Corrosion inhibition efficiency of organic compounds is related to their adsorption properties [16]. The adsorption of these molecules depends mainly on certain physicochemical properties of the inhibitor molecule such as, functional groups, steric factor, aromaticity, electron density at the donor atoms and $\pi$ orbital character of donating electrons and electronic structure of the molecules [17]-[20]. Adsorption can be described by two main types of interaction as follows [21] [22].

1) Physisorption involves electrostatic forces between ionic charges or dipoles on the adsorbed species and the electric charge at metal/solution interface. In this case, the heat of adsorption is low and therefore this type of adsorption is stable only at relatively low temperature.

2) Chemisorption involves charge sharing or charge transfer from the inhibitor molecules to the metal surface to form a coordinate type bond. In fact, electron transfer is typically for transition metals having vacant lowenergy electron orbital. Chemisorption is typified by much stronger adsorption energy than physical adsorption. Such a bond is therefore more stable at higher temperatures. Molecules that contain both nitrogen and sulfur in their structure are of particular importance, since these provide an excellent inhibition in comparison to that containing only sulfur or nitrogen atoms [23] [24]. Organic molecules could be adsorbed on the metal surface by one of the four following mechanisms.

1) Electrostatic interaction between charged surface of metal and the charge of the inhibitor.

2) Interaction of unshared electron pairs in the inhibitor molecule with the metal.

3 ) Interaction of $\pi$-electron with metal and d-A combination of the 1) - 3) types [25] [26]. The purpose of this paper is to evaluate a new synthesis of benzothiazol derivative [2(Benzo[d]thiazol-2-ylamino)-2-(2-hydroxyphenyl) acetonitrile] as corrosion inhibitor for carbon steel in artificial sea water $(3.5 \% \mathrm{NaCl})$. The adsorption and inhibition efficiency of this inhibitor were investigated and thermodynamic adsorption parameters in absence and present of this inhibitor were calculated.

$\alpha$-Amino nitriles have occupied an important, although often understated, position in organic chemistry ever since Strecker's original report in 1850 on the three component reaction. Now bear his name, among aldehydes, ammonia and hydrogen cyanide [27]. $\alpha$-amino nitriles are useful intermediates for the synthesis of amino acids [28] [29]. These bifunctional compounds have subsequently been shown to be versatile intermediates in a number of synthetic applications. Strecker synthesis and subsequent nitrile hydrolysis are indeed a very convenient method for accessing non-protein genic $\alpha$-amino acids [30]. The classical Strecker reaction was clarified bellow:

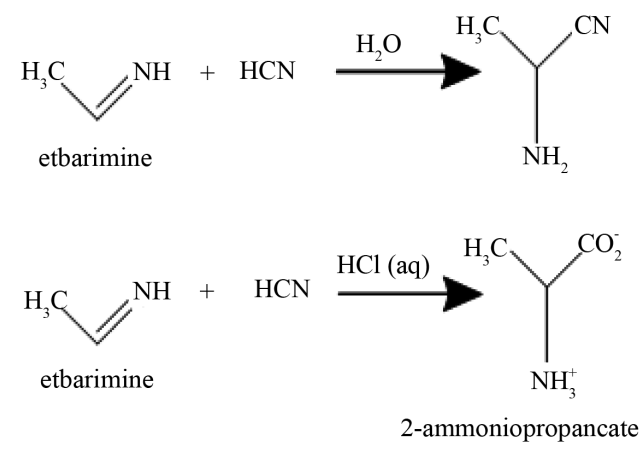

\section{Experimental}

\subsection{Instruments and Materials}

All the chemicals and solvents which are used for the synthesis were of reagent grade and obtained commer- 
cially from British Drug House (BDH). Melting point was determined on a Gllenkamp melting point apparatus. The infrared spectra of the ligand and its complexes were recorded in the range $(4000-400) \mathrm{cm}^{-1}$ on a Shimadzu (8300) FTIR Spectrophotometer, using CsI pellets. Elemental analysis for carbon, hydrogen and nitrogen elements were carried out at the Euro vecter-EA3000A C. H. N. Analyzer, Al al-Bayt University (Jordan). ${ }^{1} \mathrm{HNMR}$ and ${ }^{13} \mathrm{C}$-NMR spectra was recorded on a make Bruker model ultrashied $300 \mathrm{MHz}$, NMR at AhlAl-Bait University (Jordan).

\subsection{Preparation Method of 2(Benzo[d]thiazol-2-ylamino)-2-(2-hydroxy-phenyl) Acetonitrile}

A general method [31] [32] can be adopted for preparation which can be described as follows: The 2-hydroxybenzaldehyde $(1 \mathrm{mmol})$ was added to $(20 \mathrm{ml})$ glacial acetic acid, p-toluene sulphonic acid was added in very small portion as catalyst, followed by addition of $(1 \mathrm{mmol})$ benzothiazol-2-ylamine. The $\mathrm{pH}$ was adjusted to about 4 by addition of concentrated sulfuric acid drop wise to obtain Schiff base which stirred for $30 \mathrm{~min}$. Potassium cyanide $(2 \mathrm{mmol})$ was added to the mixture and kept under stirring for 4 days. The reaction mixture was poured into ice and then made slightly alkaline with ammonium hydroxide solution. The solid precipitate which formed was filtered, washed with water and air dried. The presence of nitrile group in the prepared $\alpha$-amino nitrile was indicated by treating few amount of the sample with $10 \%$ sodium hydroxide solution, the liberation of ammonia after hydrolysis of nitrile group, which was detected by wet red litmus paper, indicating the presence of nitrile group.

\subsection{Corrosion Measurement}

The electrolyte solution $(3.5 \% \mathrm{NaCl})$, was prepared from reagent grade $\mathrm{NaCl}$. The corrosion cell used had three electrodes, the reference electrode was a silver/silver chloride electrode., the platinum electrode was used as auxiliary electrode, and the working electrode was carbon steel specimens and the preparation procedure was as follows: thin disks with section-area of $1 \mathrm{~cm}^{2}$ were cut from the carbon steel (CK45) sheet with chemical analysis of; C (0.45), S (<0.030), Mn (0.65), Si $(0.25)$ (wt\%) and Fe (remainder). Carbon steel disks were mechanically ground down by 1200 grit abrasive $\mathrm{SiC}$ papers, then washed with distilled water and methanol and dried in warm and dry air flow.

The electrochemical measurement were carried out using advanced computerized potentiostatmodel Wenking MLab-200 of Bank Elektronik-Intellignt controls GmbH (Germany) and jacketed Pyrex glass cell. Polarization curves were recorded at constant sweep rate of $2 \mathrm{mv} / \mathrm{s}$ and scanning range was from -200 to $+200 \mathrm{mv}$ with respect to the open circuit potential. Before each experiment, the working electrode was immersed in the test cell for $30 \mathrm{~min}$ until to reach steady state condition. All tests were carried out at constant temperature (within $\pm 1^{\circ} \mathrm{C}$ ) by controlling the cell temperature using a cooling heating circulating water bath.

\section{Result and Discussion}

\subsection{Preparation and Identification Benzothiazol Derivative}

Purity of the obtained compound was examined by TLC, using chloroform and ethyl acetate (1:1) as effluent. The product color was brown yellow and the yield percentage was $(83.76 \%)$ and the melting point was $\left(70^{\circ} \mathrm{C}\right.$ $71^{\circ} \mathrm{C}$ ). The reaction was clarified below:

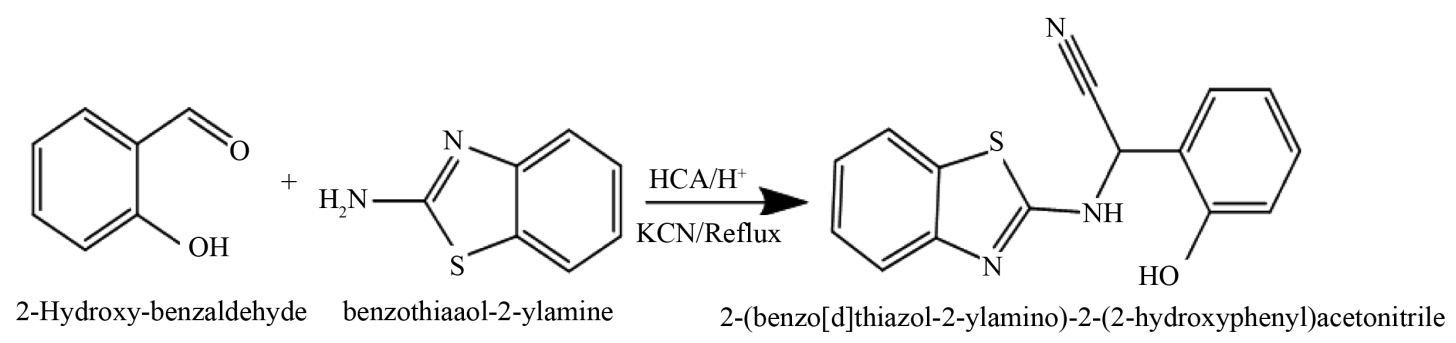

The elemental analysis and some physical properties of the compound are in Table 1 . The significant FTIR bands Figure 1 of (Benzothiazol-2-ylamino) (2-hydroxy-phenyl)-acetonitrile compound and its assignments are 
Table 1. Some physical properties and elemental analysis of 2(Benzo[d]thiazol-2-ylamino)-2-(2-hydroxy-phenyl) acetonitrile.

\begin{tabular}{|c|c|c|c|c|c|c|c|}
\hline \multirow{2}{*}{$\begin{array}{c}\text { Empirical Formula } \\
\text { Mwt }\end{array}$} & \multirow{2}{*}{ Color } & \multirow{2}{*}{ M.P. ${ }^{\circ} \mathrm{C}$} & \multirow{2}{*}{ Yield \% } & \multicolumn{4}{|c|}{ Elemental Analysis Calculated (Found) } \\
\hline & & & & $\mathrm{C} \%$ & $\mathrm{H} \%$ & $\mathrm{~N} \%$ & S\% \\
\hline $\mathrm{C}_{15} \mathrm{H}_{11} \mathrm{~N}_{3} \mathrm{SO} 281$ & yellow orange & $70-71$ & 83.76 & $\begin{array}{c}64.06 \\
(63.87)\end{array}$ & $\begin{array}{c}3.91 \\
(3.75)\end{array}$ & $\begin{array}{c}14.95 \\
(14.77)\end{array}$ & $\begin{array}{r}11.39 \\
(11.17)\end{array}$ \\
\hline
\end{tabular}

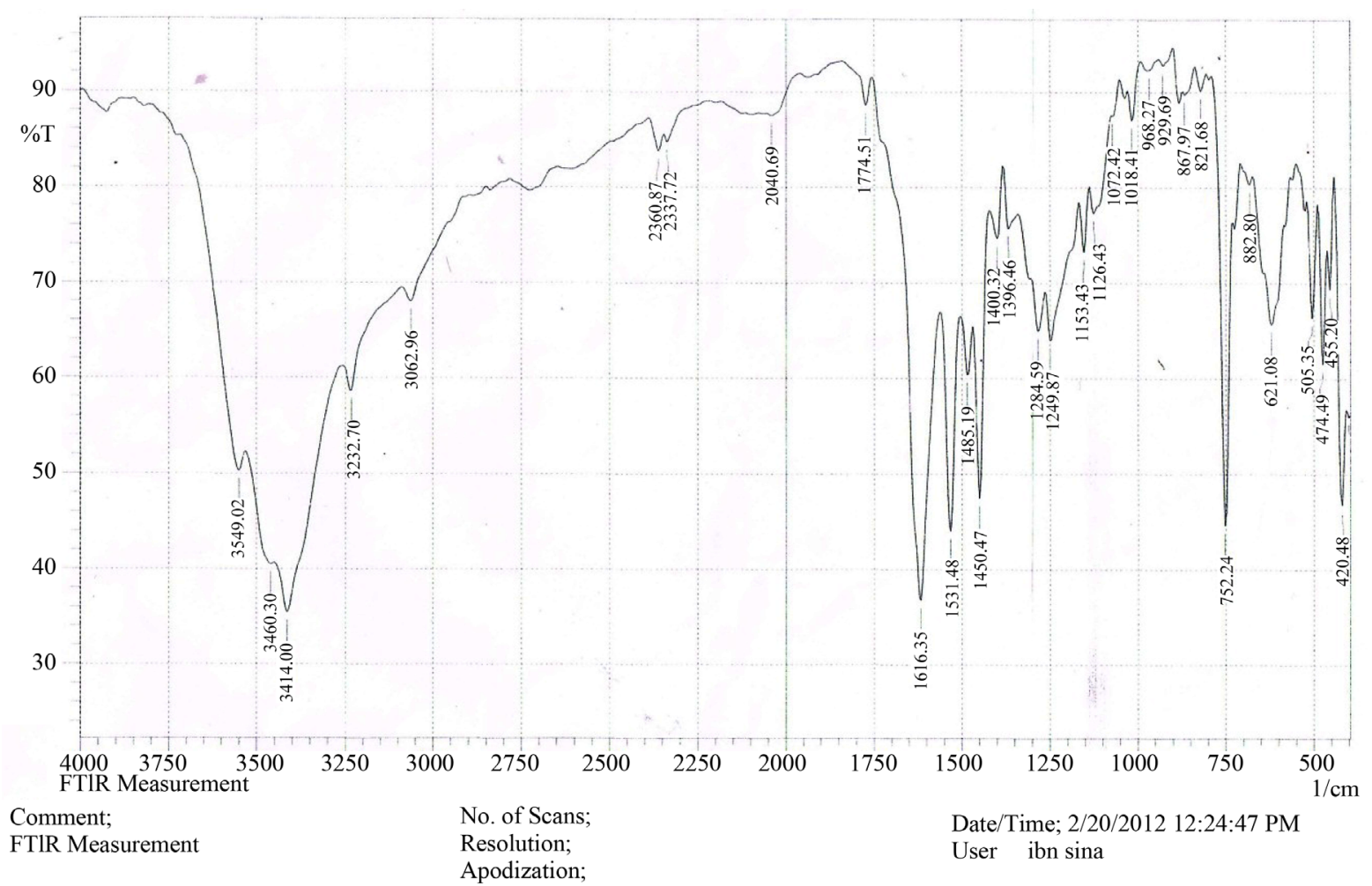

Figure 1. FT-IR spectrum of 2(Benzo[d]thiazol-2-ylamino)-2-(2-hydroxy-phenyl) acetonitrile.

given in Table 2. The FTIR showed some characteristic bands related to $\alpha$-amino nitriles; like $2337 \mathrm{~cm}^{-1}$ which could be attributed to $v(\mathrm{C} \equiv \mathrm{N})$ group [32]. Infrared spectrum showed stretching band at $3233 \mathrm{~cm}^{-1}$ for $v(\mathrm{~N}-\mathrm{H})$ band. The next characteristic band near $1616 \mathrm{~cm}^{-1}$ which could be attributed to $\delta(\mathrm{N}-\mathrm{H})$ group. The FTIR spectrum also showed a characteristic aromatic bands at $3062 \mathrm{~cm}^{-1}$ and out of plane bending at $752 \mathrm{~cm}^{-1}$ for ortho-substituted benzene ring, while it showed the disappearance of $(\mathrm{C}=\mathrm{O})$ band [33] [34]. The ${ }^{1} \mathrm{H}$ NMR spectra Figure 2 of the same compound in DMSO with assignments are collected in Table 3 . The ${ }^{1} \mathrm{H}$ NMR spectra showed besides the aromatic proton signals at $7-7.7 \mathrm{ppm}$, the phenolic $\mathrm{OH}$ proton has a signal $5.6 \mathrm{ppm}$ the signals due to $\mathrm{NH}$ and $\mathrm{CH}$ appear at 3.4 and $4.8 \mathrm{ppm}$, respectively [35] [36]. ${ }^{13} \mathrm{C}$ NMR spectrum Figure 3 shows result which was listed in Table 4.

\subsection{Effect of Inhibitor Concentration}

Figures 4(a)-(d) show the polarization curves for carbon steel in $3.5 \% \mathrm{NaCl}$ in present and absent of different inhibitor concentration ranging between $(10-1000) \mathrm{ppm}$, in temperature range (298 - 323) K. Electrochemical parameters such as corrosion potential $\left(E_{\text {corr }}\right)$, cathodic and anodic Tafel slopes (bc and ba) and corrosion current density $\left(i_{\text {corr }}\right)$ were extracted by Tafel extrapolating the anodic and cathodic lines and are listed in Table 5.

The degree of surface coverage $(\theta)$ and the percentage of protection efficiency $(\mathrm{P} \%)$ were calculated using the following equations [23] [26]:

$$
\theta=i_{\text {ocorr }}-i_{\text {corr }} / i_{\text {ocorr }}
$$


Table 2. The characteristic bands of FTIR spectra of Benzo[d]thiazol-2-ylamino)-2-(2-hydroxy-phenyl) acetonitrile in $\left(\mathrm{cm}^{-1}\right)$.

\begin{tabular}{|c|c|c|c|c|c|c|c|}
\hline $\mathrm{C}_{15} \mathrm{H}_{11} \mathrm{~N}_{3} \mathrm{SO}$ & vO-H cm cm $^{-1}$ & $v \mathrm{~N}-\mathrm{H} \mathrm{cm} \mathrm{cm}^{-1}$ & $\begin{array}{l}\text { UC-H cm co } \\
\text { Aliphatic }\end{array}$ & $\begin{array}{l}\text { vC-H cm-1 } \\
\text { Aromatic }\end{array}$ & $\begin{array}{l}\delta \mathrm{C}-\mathrm{H} \mathrm{cm} \mathrm{cm}^{-1} \\
\text { Aromatic }\end{array}$ & $\begin{array}{l}v \mathrm{C} \equiv \mathbf{N} \\
\text { Nitrile }\end{array}$ & $\delta \mathrm{N}-\mathrm{H}$ \\
\hline & 3414 & 3233 & 2970 & 3062 & 752 & 2237 & 1616 \\
\hline
\end{tabular}

Table 3. ${ }^{1} \mathrm{H}$ NMR data for the 2(Benzo[d]thiazol-2-ylamino)-2-(2-hydroxy-phenyl) acetonitrile in DMSO solution (ppm) $\delta-H$.

\begin{tabular}{ccccc}
$\mathrm{C}_{15} \mathrm{H}_{11} \mathrm{~N}_{3} \mathrm{SO}$ & Aromatic Protons & Phenolic $\mathrm{OH}$ Proton & NH Proton & CH Proton \\
\hline $7.0-7.7$ & 5.6 & 3.4 & 4.8 \\
\hline
\end{tabular}

Table 4. ${ }^{13} \mathrm{C}$ NMR data for 2(Benzo[d]thiazol-2-ylamino)-2-(2-hydroxy-phenyl) acetonitrile.

$\begin{array}{cccccc}{ }^{1} \mathbf{C} & { }^{2} \mathbf{C} & { }^{8} \mathbf{C} & \begin{array}{c}\text { C of All } \\ \text { Aromatic }\end{array} \\ { }^{9} \mathbf{C} & 150.5 & 120-130\end{array}$

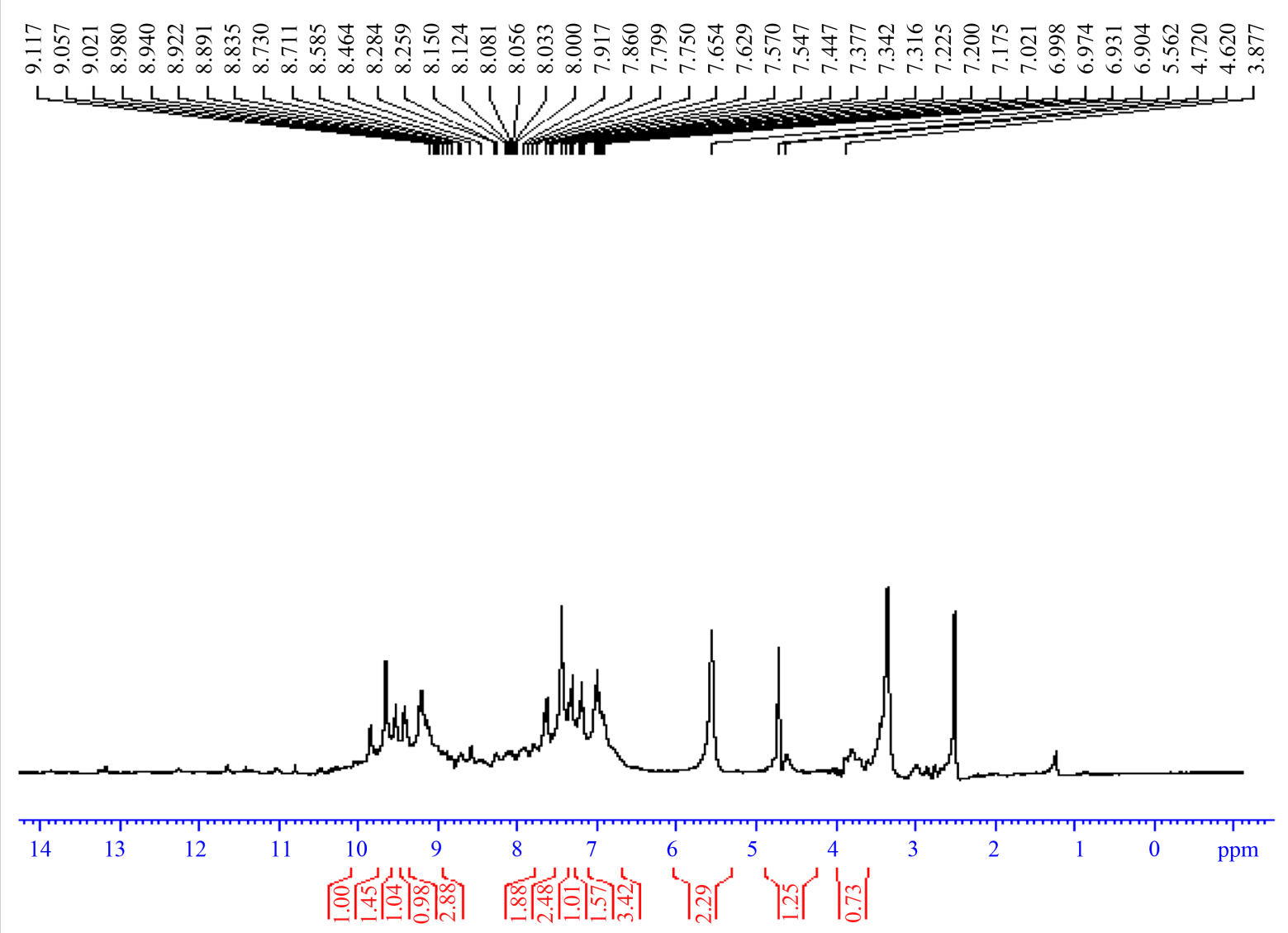

Figure 2. ${ }^{1}$ H-NMR spectrum of 2(Benzo[d]thiazol-2-ylamino)-2-(2-hydroxy-phenyl) acetonitrile. 


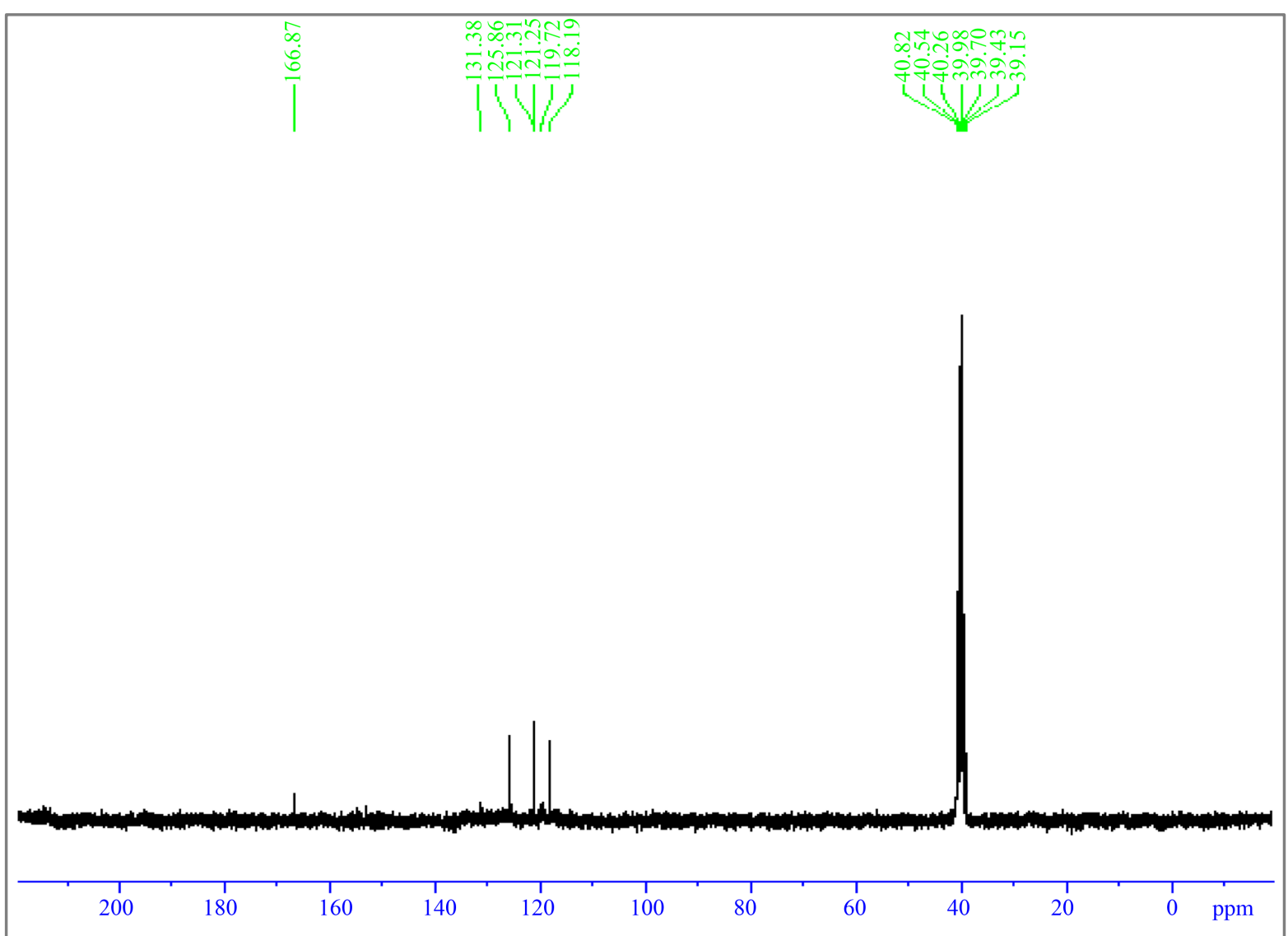

Figure $3 .{ }^{13} \mathrm{C}$-NMR spectrum of 2(Benzo[d]thiazol-2-ylamino)-2-(2-hydroxy-phenyl) acetonitrile.

$$
P \%=\theta \times 100
$$

where $i_{\text {ocorr }}$ and $i_{\text {corr }}$ are corrosioncurrent densities in the absent and present of inhibitor, respectively. From the result in Table 1, it can be observed that the values of corrosion current density $\left(i_{\text {corr }}\right)$ of carbon steel in the inhibitor-containing solutions were lower than those for the inhibitor-free solution. The corrosion current densities at all inhibitor concentration are decreased.

\subsection{Adsorption Isotherms}

Adsorption isotherms provide information about the interaction of the adsorption molecules with the electrode surface [28]. The adsorption of an organic adsorb ate at metal-solution interface can be presented as substitution adsorption process between the organic molecules in aqueous solution, $\left(\operatorname{Org}_{(\mathrm{sol})}\right)$, and the water molecules on metallic surface, $\left(\mathrm{H}_{2} \mathrm{O}_{(\text {ads })}\right)[25]$.

$$
\left(\mathrm{Org}_{(\mathrm{sol})}\right)+\mathrm{XH}_{2} \mathrm{O}_{(\text {ads })} \leftrightarrow \mathrm{Org}_{(\text {ads })}+\mathrm{H}_{2} \mathrm{O}_{(\text {sol })}
$$

$\left(\mathrm{Org}_{(\mathrm{sol})}\right)$ and $\mathrm{Org}_{(\mathrm{ads})}$ are organic species dissolved in the aqueous solution and adsorbed onto the metallic surface, respectively, $\mathrm{H}_{2} \mathrm{O}_{(\mathrm{ads})}$ is the water molecule adsorbed on the metallic surface and $\mathrm{X}$ is the size ratio respectively, the number of water molecules replaced by one organic adsorb ate. For the studied inhibitor, it was found that the experimental data obtained from polarization reading could be fitted by Langmuir isotherm and Frumkin's isotherm. Among the tow isotherms, the best fit adsorption isotherm is the Frumkin adsorption isotherm for adsorption of inhibitor on carbon steel surface with the mean $\mathrm{R}^{2}$ value 0.9989 . This means that there is an adsorption on a homogenous surface with interaction in the adsorption layer and the negative "a" value suggested that there is a decrease in the adsorption energy that is caused by the repulsive lateral force between the molecules in the adsorbed layer. The inhibitor follows Frumkin adsorption isotherm. The adsorption on a 


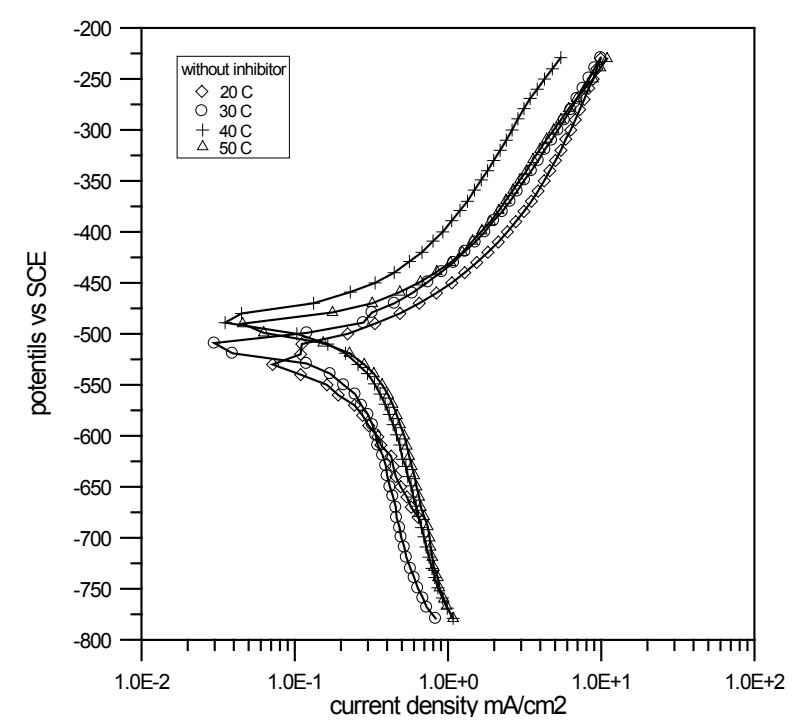

(a)

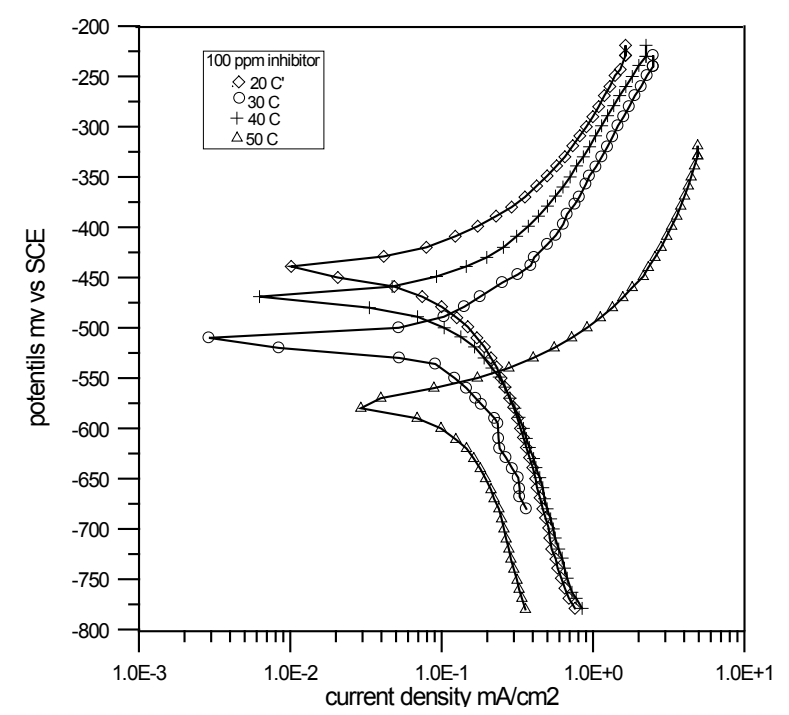

(c)

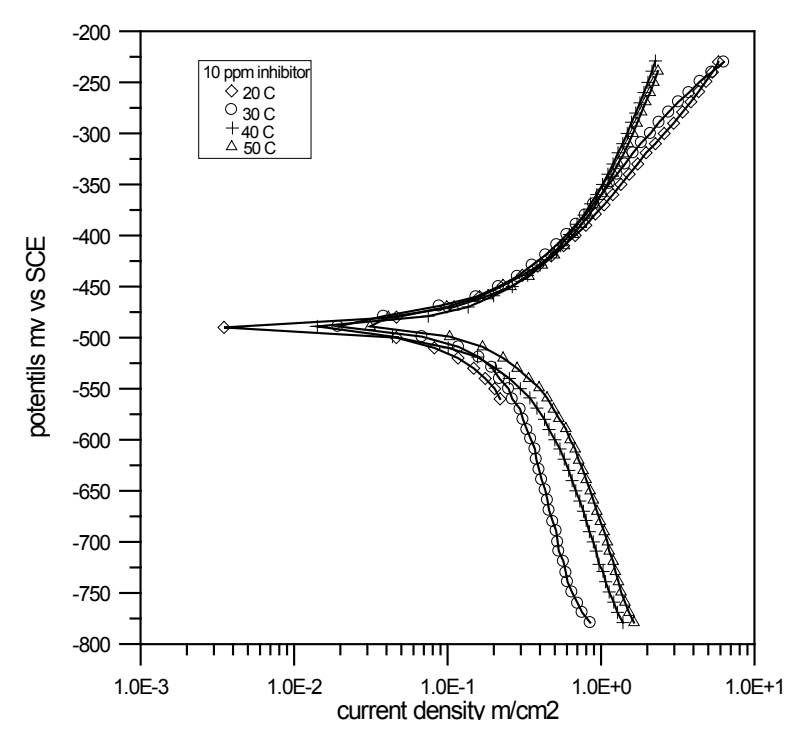

(b)

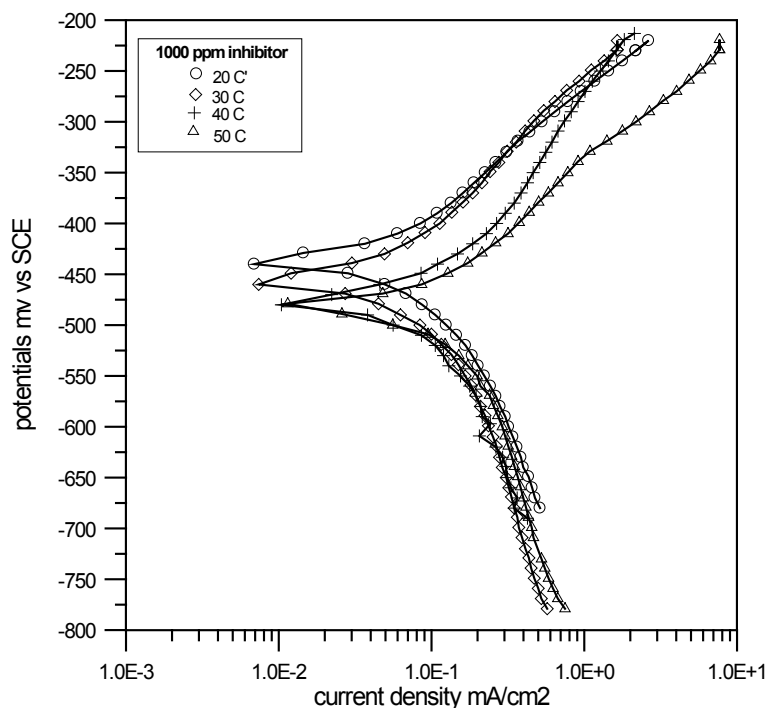

(d)

Figure 4. Tafel plots of carbon steel in 3.5\% NaCl: (a) without inhibitor; (b) 10 ppm; (c) 100 ppm; (d) 1000 ppm at different temperatures.

homogenous surface with an interaction in the adsorption layer obeys Frumkin's isotherm [26].

The equation of Frumkin isotherm is;

$$
\{\theta /(1-\theta)\} \mathrm{e}^{-2 a \theta}=K C
$$

Taking log on the both sides, it becomes;

$$
\log \{\theta /(1-\theta) C\}=\log K+2 a \theta
$$

where " $a$ " is the interaction parameter which can be positive or negative. A positive value indicates that the adsorption energy is increased by the lateral attraction between the adsorbed molecules and the negative values suggest that there is the presence of the lateral force of repulsion between the molecules in the adsorbed layer. Therefore, inhibitor after adsorption through $\mathrm{N}, \mathrm{O}, \mathrm{S}$, atoms on the metal surface experiences lateral repulsive interactions among the $\mathrm{N}, \mathrm{CN}, \mathrm{OH}, \mathrm{S}=$. This also supplements that the adsorption of this inhibitor occurs via donation of electrons of $\mathrm{N}, \mathrm{O}, \mathrm{S}$ atoms to the metal. 


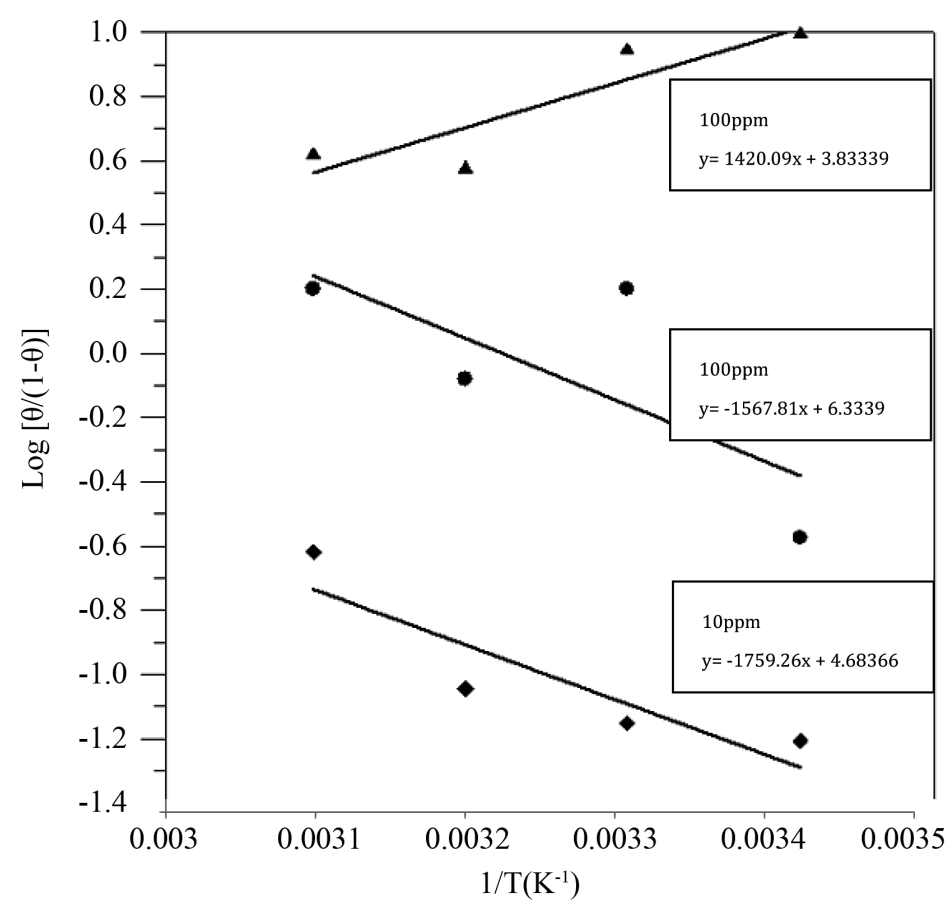

Figure $5 . \log [\theta /(1-\theta)]$ against $1 / T$ plots of carbon steel in sea water without and with different concentration of the prepared inhibitor.

From Figure 5 values of $K$ and " $a$ " are calculated from intercept and slope, respectively.

The value of free energy of adsorption $(\Delta G)_{\text {ads }}$ are calculated by using the following equation [37].

$$
\Delta G_{a d s}=-R T \ln 55.5 \mathrm{~K}
$$

The various values are tabulated in the Table 5. The mean value of $\Delta G_{a d s}$ for this isotherm is $-34.2595 \mathrm{~kJ} / \mathrm{mol}$. The negative value of $\Delta G_{\text {ads }}$ indicates the spontaneity of the adsorption process and the stability of the adsorbed layer on the carbon steel surface. The low $\Delta G_{a d s}$ value in the present case further confirms physical adsorption. Gibbs free energy values, $\Delta G_{\text {ads }}$ between $-49 \mathrm{~kJ} / \mathrm{mol}$ and $-58 \mathrm{~kJ} / \mathrm{mol}$ are indicative of chemisorption to Bereket et al. [38]. The low $\Delta G_{a d s}$ value in the present case further confirms physical adsorption.

\subsection{Effect of Temperature}

The data in Table 7 reveal the effect of temperature on $i_{\text {corr }}$ and $\mathrm{WL}\left(\mathrm{g} / \mathrm{m}^{2} \cdot \mathrm{d}\right), \mathrm{CR}(\mathrm{mm} / \mathrm{y})$, and P\% for carbon steel in $3.5 \% \mathrm{NaCl}$ solution. The result suggests that the inhibitor slightly adsorbed on carbon steel surface at all temperatures studied. The value of $\mathrm{P} \%$ of different inhibitor concentration generally decreases with the increase of temperature. The apparent activation energy $\left(E a^{*}\right)$ for the corrosion process in absence and presence of the inhibitor was evaluated from Arrhenius equation [28]:

$$
\log R_{\text {corr }}=\log A-E a^{*} / 2.303 R T
$$

where $R_{\text {corr }}$ is the corrosion rate $A$ is the frequency factor and $E a^{*}$ is the apparent activation energy, $R$ is universal gas constant $\left(8.314 \mathrm{~J} \cdot \mathrm{mol}^{-1} \cdot \mathrm{K}^{-1}\right)$.

The plot of logarithm of corrosion rate of carbon steel obtained from corrosion current densities versus the reciprocal of absolute temperature rang $(293-323) \mathrm{K}$, give straight lines with slope of $-E a^{*} / 2.303 R T$ as shown in Figure 6.

The thermodynamic parameters of carbon steel in $3.5 \% \mathrm{NaCl}$ media in absence and in presence of inhibitor under test are given and they can be calculated using transition state Equation (11) [39].

$$
C R_{r}=R T / N h \mathrm{e}^{\Delta S^{*} / R} \cdot \mathrm{e}^{\Delta H^{*} / R T}
$$

where $C R$ is the corrosion rate, $E a$ is the apparent activation energy, $R$ is the universal gas constant ( 8.314 
Table 5. Equilibrium constant and Gibbs free energy values for the inhibitor at various temperatures calculated from Frumkin isotherm.

\begin{tabular}{ccccc}
\hline Temp & $\boldsymbol{a}$ & $\boldsymbol{K}$ & $\boldsymbol{R}^{\mathbf{2}}$ & $\boldsymbol{\Delta} \boldsymbol{G}_{\boldsymbol{a d d}} / \mathbf{K J} \cdot \mathbf{m o l}^{-\mathbf{1}}$ \\
293 & -0.972 & 27.352 & 0.9988 & -34.671 \\
303 & -0.996 & 6.8077 & 1.0000 & -14.950 \\
313 & -1.7305 & 92.683 & 0.9967 & -40.161 \\
323 & -2.328 & 790.678 & 0.9999 & -47.256 \\
\hline
\end{tabular}

Table 6. Polarization measurements summary of carbon steel specimens in artificial sea water $(3.5 \% \mathrm{NaCl}) /$ inhibitor at different temperatures.

\begin{tabular}{|c|c|c|c|c|c|c|c|c|c|}
\hline $\begin{array}{c}\text { System } \\
(3.5 \% \mathrm{NaCl})\end{array}$ & $\underset{{ }^{\circ} \mathrm{C}}{\text { Temp. }}$ & $\begin{array}{c}\text { Ecorr } \\
\text { mv vs. SCE }\end{array}$ & $\begin{array}{c}i_{\text {corr }} \\
\mu \mathrm{A} / \mathbf{c m}^{2}\end{array}$ & $\begin{array}{c}|\mathbf{a}| \\
\mathrm{mV} / \mathrm{Dec}\end{array}$ & $\begin{array}{c}\mathbf{b} \\
\mathrm{mV} / \mathrm{Dec}\end{array}$ & $\begin{array}{l}W L \\
g / m^{2} \cdot d\end{array}$ & $\underset{\mathrm{mm} / \mathrm{y}}{\mathrm{CR}}$ & $\mathbf{P} \%$ & $\boldsymbol{\theta}$ \\
\hline Without Inhibitor & 293 & -526 & 126 & 168 & 80 & 31.6 & 1.47 & - & - \\
\hline$=$ & 303 & -512 & 143 & 213 & 90 & 36.0 & 1.65 & - & - \\
\hline$=$ & 313 & -489 & 150 & 177 & 109 & 37.6 & 1.75 & - & - \\
\hline$=$ & 323 & -497 & 204 & 214 & 96 & 51.0 & 2.37 & - & - \\
\hline 10 ppm Inhibitor & 293 & -563 & 97 & 171 & 101 & 24.5 & 1.14 & 23.01 & 0.23 \\
\hline$=$ & 303 & -484 & 108 & 189 & 109 & 36.0 & 1.26 & 24.47 & 0.24 \\
\hline$=$ & 313 & -489 & 110 & 144 & 108 & 27.6 & 1.28 & 26.66 & 0.26 \\
\hline$=$ & 323 & -468 & 132 & 135 & 117 & 33.0 & 1.53 & 35.29 & 0.35 \\
\hline 100 ppm Inhibitor & 293 & -440 & 55 & 143 & 85 & 13.8 & 0.64 & 56.34 & 0.36 \\
\hline$=$ & 303 & -510 & 64 & 141 & 92 & 16.0 & 0.63 & 55.24 & 0.55 \\
\hline$=$ & 313 & -469 & 78 & 162 & 100 & 19.6 & 0.90 & 48.00 & 0.48 \\
\hline$=$ & 323 & -578 & 90 & 203 & 78 & 22.5 & 1.04 & 55.88 & 0.55 \\
\hline 1000 ppm Inhibitor & 293 & -455 & 34 & 120 & 112 & 8.57 & 0.40 & 73.01 & 0.73 \\
\hline$=$ & 303 & -439 & 40 & 124 & 115 & 10.0 & 0.46 & 72.02 & 0.72 \\
\hline$=$ & 313 & -474 & 54 & 167 & 104 & 13.5 & 0.63 & 64.00 & 0.64 \\
\hline$=$ & 323 & -476 & 72 & 175 & 101 & 18.1 & 0.84 & 64.78 & 0.65 \\
\hline
\end{tabular}

$\left.\mathrm{J} \cdot \mathrm{mol}^{-1} \cdot \mathrm{K}^{-1}\right), T$ is temperature, $A$ is the Arrhenius pre-exponential factor, $h$ is the Plank's constant $(6.626176 \times$ $1034 \mathrm{~J} \cdot \mathrm{s}), N$ is the Avogadro's number $\left(6.022 \times 10^{23} \mathrm{~mol}^{-1}\right), \Delta S^{*}$ is the entropy of activation and $\Delta H^{*}$ is the enthalpy of activation. The values of $E a^{*}, \Delta H^{*}$ and $\Delta S^{*}$ were calculated as shown in Figure 7 which represents the plot of $\log \left(C R_{r} / T\right)$ against $(1 / T)$.

Straight lines are obtained with a slope of $\left(-\Delta H^{*} / 2.303 R\right)$ and an intercept of $\left(\log R / N h+\Delta S^{*} / 2.303 R\right)$ from which the values of $\Delta H^{*}$ and $\Delta S^{*}$ were calculated. Then $\Delta G^{*}$ calculated using the following equation:

$$
\Delta G^{*}=\Delta H^{*}-T \Delta S^{*}
$$

and listed in Table 7.

Analysis of the temperature dependence of inhibition efficiency as well as comparison of corrosion activation in absence and in presence of the inhibitors give some insight into the possible mechanism of inhibitor adsorption. A decrease in inhibition efficiency with rise in temperature, with analogous increase in corrosion activation energy in the presence of $(100,1000)$ ppm compared to its absence, is frequently interpreted as being suggestive of a physical adsorption [40].

Also the lower $\Delta H^{*}$ values indicate that the inhibited corrosion reaction of carbon steel is supporting the proposed physisorption mechanism [34] [41]. The entropy of activation $\Delta S^{*}$ in the presence inhibitor is small and negative values. This implies that the activated complex in the rate determining step represents dissociation rather 


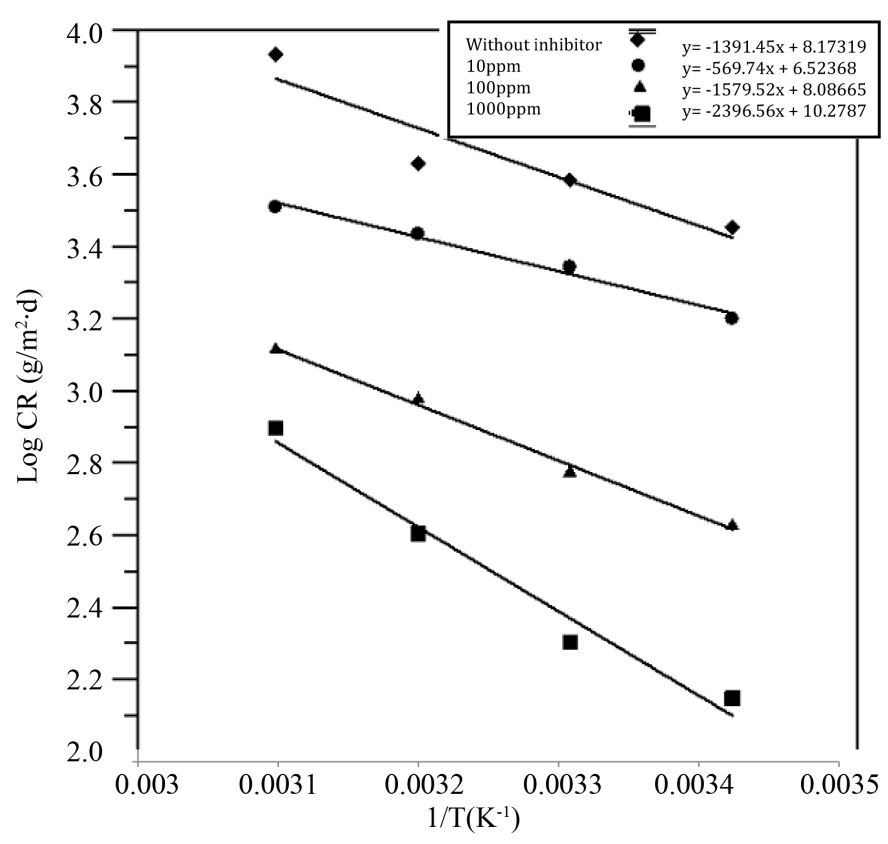

Figure 6. Arrhenius plots of carbon steel in sea water without and with different concentration of the prepared inhibitor.

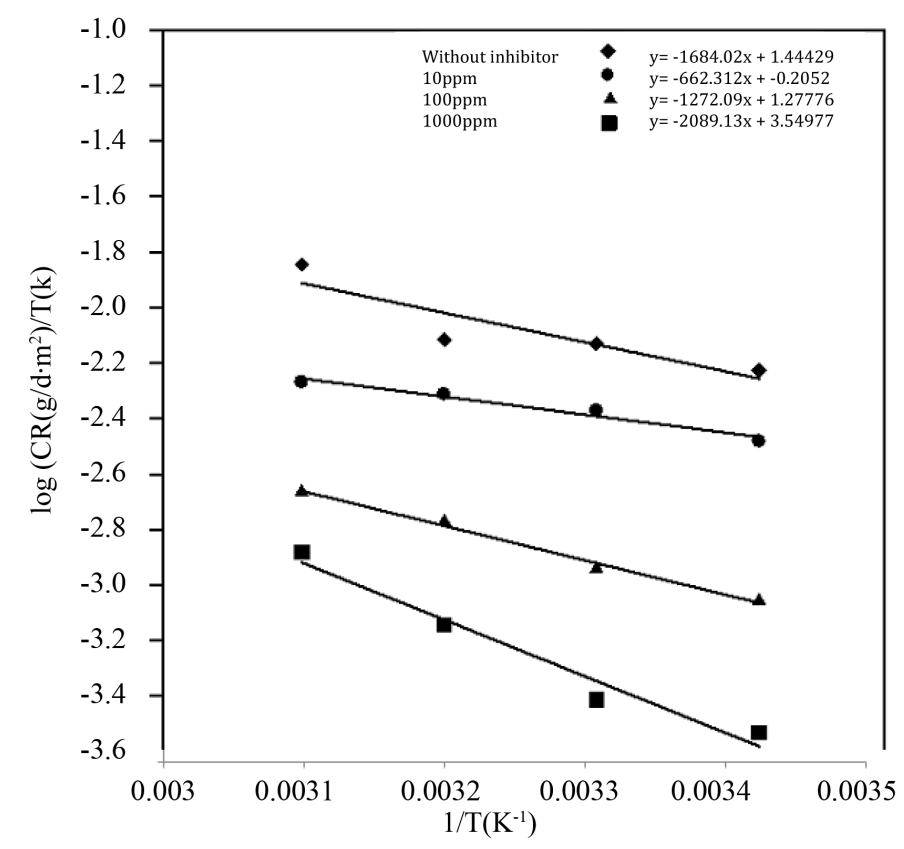

Figure 7. $\log [\mathrm{CR}(\mathrm{g} / \mathrm{d} \cdot \mathrm{m}-2) / \mathrm{T}(\mathrm{K}-1)]$ against $1 / \mathrm{T}(\mathrm{K}-1)$ plots of carbon steel in sea water without and with different concentration of the prepared inhibitor.

than association meaning that the increase in a disordering takes place on going from activated complex to reactants, which $\Delta S^{*}$ values In absence of inhibitor is more small and negative that indicate to the association rather than of presence inhibitor [41].

The activation energy for corrosion reaction with using $10 \mathrm{ppm}$ inhibitor was lower than in absence of inhibitor, that indicate the increasing in the ability of the corrosion rate a cording to uncompleted adsorption layer but $\log$ A values decreased with adding low inhibitor concentration. 
Table 7. The values of activation parameters $E a^{*}, \Delta H^{*}, \Delta S^{*}$, and $\Delta G^{*}$ for carbon steel in $3.5 \% \mathrm{NaCl}$ in absence and presence of different inhibitor concentration $(10,100,1000) \mathrm{ppm}$.

\begin{tabular}{|c|c|c|c|c|c|c|c|}
\hline \multirow{2}{*}{ Inhibitor Conc. } & \multirow{2}{*}{$\underset{\mathrm{kJ} \cdot \mathrm{mol}^{-1}}{E a^{*}}$} & \multirow{2}{*}{$\underset{\mathbf{k J} \cdot \mathbf{m o l}^{-1}}{\Delta H^{*}}$} & \multirow{2}{*}{$\begin{array}{c}\Delta S^{*} / \\
\mathbf{J} \cdot \mathbf{m o l}^{-1} \cdot \mathbf{K}^{-1}\end{array}$} & \multicolumn{4}{|c|}{$\Delta G^{*} / \mathrm{kJ} \cdot \mathrm{mol}^{-1}$} \\
\hline & & & & $20 \mathrm{C}$ & $30 \mathrm{C}$ & $40 \mathrm{C}$ & $50 \mathrm{C}$ \\
\hline $\mathbf{0}$ & 11.660 & 19.8713 & -252.70 & 93.60 & 96.15 & 98.67 & 101.20 \\
\hline 10 & 7.3850 & 4.8253 & -305.30 & 93.94 & 97.15 & 100.35 & 103.56 \\
\hline 100 & 13.192 & 10.6306 & -290.18 & 95.60 & 98.50 & 101.40 & 104.30 \\
\hline 1000 & 20.018 & 17.4576 & -271.20 & 96.56 & 99.26 & 101.96 & 104.66 \\
\hline
\end{tabular}

\section{Conclusion}

2-(Benzo[d]thiazol-2-ylamino)-2-(2-hydroxy-phenyl) acetonitrile was prepared and identified successfully, then used as corrosion inhibitor. The value of $i_{\text {corr }}$ in case of presence of inhibitor in the three concentrations was lower than $i_{\text {corr }}$ in absence of inhibitor. A best protection efficiency was $73.01 \%$ in the case using $1000 \mathrm{ppm}$ of the inhibitor at $293 \mathrm{~K}$, and by increasing temperature, protection efficiency decreased in general; the kinetics and thermodynamic study showed that the inhibitive action took place through the physisorption of the inhibitor molecules on the carbon steel surface and that the adsorption of inhibitor on carbon steel surface obeyed Frumkin isotherm.

\section{References}

[1] LaQue, F.L. (1975) Marine Corrosion and Prevention. John Wiley \& Sons, Hoboken, 116.

[2] Prabhu, R.A., Venkatesha, T.V., Shanbhag, A.V., Kulkarni, G.M. and Kalkhambkar, R.G. (2008) Inhibition Effects of Some Schiff's Bases on the Corrosion of Mild Steel in Hydrochloric Acid Solution. Corrosion Science, 50, 3356-3362. http://dx.doi.org/10.1016/j.corsci.2008.09.009

[3] Han, L. and Song, S. (2008) A Measurement System Based on Electrochemical Frequency Modulation Technique for Monitoring the Early Corrosion of Mild Steel in Seawater. Corrosion Science, 50, 1551-1557. http://dx.doi.org/10.1016/j.corsci.2008.02.009

[4] Melchers, R.E. and Jeffrey, R. (2005) Early Corrosion of Mild Steel in Seawater. Corrosion Science, 47, $1678-1693$. http://dx.doi.org/10.1016/j.corsci.2004.08.006

[5] Bousselmi, L., Fiaud, C., Tribollet, B. and Triki, E. (1997) The Characterisation of the Coated Layer at the Interface Carbon Steel-Natural Salt Water by Impedance Spectroscopy. Corrosion Science, 39, 1711-1724. http://dx.doi.org/10.1016/S0010-938X(97)00077-2

[6] Bregmann, J.I. (1963) Corrosion Inhibitors. Macmillan P T, New York.

[7] Hackerman, N. (1987) The Theory and Practice of Corrosion and Its Control in Industry. Langmuir, 3, 922-930. http://dx.doi.org/10.1021/la00078a009

[8] Nathan, C.C. (1977) Organic Inhibitors. NACE, Houston.

[9] Trabanelli, G. and Garaaiti, V., Fontana, M.G. and Staehle, R.W. (1970) Advances in Corrosion Science and Technology. Plenum Press, New York, 147. http://dx.doi.org/10.1007/978-1-4615-8252-6_3

[10] Kaesche, H. and Hacherman, N. (1958) Corrosion Inhibition by Organic Amines. Journal of the Electrochemical Society, 105, 191-198. http://dx.doi.org/10.1149/1.2428796

[11] Blomgren, E. and Bockriss, J.O.M. (1959) The Adsorption of Aromatic Amines at the Interface: Mercury-Aqueous Acid Solution. The Journal of Physical Chemistry, 63, 1475-1484. http://dx.doi.org/10.1021/j150579a037

[12] Granese, S.L. (1987) Study of the Inhibitory Action of Nitrogen-Containing Compounds. Corrosion, 44, $322-327$. http://dx.doi.org/10.5006/1.3583944

[13] Notoya, T. (1978) Journal of Corrosion Engineering Japan, 27, 661.

[14] Srivasthava, K. and Srivasthava, P. (1980) Corrosion Prevention and Control, $27,5$.

[15] Saleh, R.M., Ismail, A.A. and El Hosary, A.A. (1984) Corrosion Inhibition by Naturally Occurring Substances-IX. The Effect of the Aqueous Extracts of Some Seeds, Leaves, Fruits and Fruit-Peels on the Corrosion of $\mathrm{Al}$ in $\mathrm{NaOH}$. Corrosion Prevention and Control, 31, 21-23.

[16] Cruz, J., Martinez, R., Genesca, J. and Garcia-Ochoa, E. (2004) Experimental and Theoretical Study of 1-(2-Ethylamino)- 
2-methylimidazoline as an Inhibitor of Carbon Steel Corrosion in Acid Media. Journal of Electroanalytical Chemistry, 566, 111-121.

[17] Khaled, K.F. (2003) The Inhibition of Benzimidazole Derivatives on Corrosion of iron in $1 \mathrm{M} \mathrm{HCl} \mathrm{Solutions.} \mathrm{Electro-}$ chimica Acta, 48, 2493-2503. http://dx.doi.org/10.1016/S0013-4686(03)00291-3

[18] Popova, A., Christov, M., Raicheva, S. and Sokolova, E. (2004) Adsorption and Inhibitive Properties of Benzimidazole Derivatives in Acid Mild Steel Corrosion. Corrosion Science, 46, 1333-1350. http://dx.doi.org/10.1016/j.corsci.2003.09.025

[19] Bereket, G., Hur, E. and Ogretir, C. (2002) Quantum Chemical Studies on Some Imidazole Derivatives as Corrosion Inhibitors for Iron in Acidic Medium. Journal of Molecular Structure, 578, 79-88. http://dx.doi.org/10.1016/S0166-1280(01)00684-4

[20] El Ashry, S.H., El Nemr, A., Essawy, S.A. and Ragab, S. (2008) Corrosion Inhibitors Part V: QSAR of Benzimidazole and 2-Substituted Derivatives as Corrosion Inhibitors by Using the Quantum Chemical Parameters. Progress in Organic Coatings, 61, 11-20. http://dx.doi.org/10.1016/j.porgcoat.2007.08.009

[21] Noor, E.A. and Al-Moubaraki, A.H. (2008) Thermodynamic Study of Metal Corrosion and Inhibitor Adsorption Processes in Mild Steel/1-Methyl-4[4'(-X)-styryl Pyridinium Iodides/Hydrochloric Acid Systems. Materials Chemistry and Physics, 110, 145-154. http://dx.doi.org/10.1016/j.matchemphys.2008.01.028

[22] Santana Rodriguez, J.J., Motesdeoca Alvarez, C. and Gonzalez Gonzalez, J.E. (2006) EIS Characterisation of the Layer of Corrosion Products on Various Substrates in Differing Atmospheric Environments. Materials and Corrosion, 57, 350-356. http://dx.doi.org/10.1002/maco.200503872

[23] Benali, O., Larabi, L., Traisnel, M., Gengembra, L. and Harek, Y. (2007) Electrochemical, Theoretical and XPS Studies of 2-Mercapto-1-Methylimidazole Adsorption on Carbon Steel in $1 \mathrm{M} \mathrm{HClO}_{4}$. Applied Surface Science, 253, 6130 6139. http://dx.doi.org/10.1016/j.apsusc.2007.01.075

[24] Bentiss, F., Lebrini, M. and Lagrenée, M. (2005) Thermodynamic Characterization of Metal Dissolution and Inhibitor Adsorption Processes in Mild Steel/2,5-Bis(n-thienyl)-1,3,4-thiadiazoles/hydrochloric Acid System. Corrosion Science, 47, 2915-2931. http://dx.doi.org/10.1016/j.corsci.2005.05.034

[25] Naderi, E., Jafari, A.H., Ehteshamzadeh, M. and Hosseini, M.G. (2009) Effect of Carbon Steel Microstructures and Molecular Structure of Two New Schiff Base Compounds on Inhibition Performance in $1 \mathrm{M} \mathrm{HCl} \mathrm{Solution} \mathrm{by} \mathrm{EIS.} \mathrm{Ma-}$ terials Chemistry and Physics, 115, 852-858. http://dx.doi.org/10.1016/j.matchemphys.2009.03.002

[26] Bentiss, F., Lagrenee, M., Traisnel, M. and Hornez, J.C. (1999) The Corrosion Inhibition of Mild Steel in Acidic Media by a New Triazole Derivative. Corrosion Science, 41, 789-803. http://dx.doi.org/10.1016/S0010-938X(98)00153-X

[27] Strecker, A. (1850) Ueber die künstliche Bildung der Milchsäure und einen neuen, dem Glycocoll homologen Körper. Annalen der Chemie und Pharmacie, 75, 27-45. http://dx.doi.org/10.1002/jlac.18500750103

[28] Harada, K. (1963) Asymmetric Synthesis of $\alpha$-Amino-Acids by the Strecker Synthesis. Nature, 200, 1201. http://dx.doi.org/10.1038/2001201a0

[29] Evans, D.A. and Weber, A.E. (1986) Asymmetric Glycine Enolate Aldol Reactions: Synthesis of Cyclosporin's Unusual Amino Acid, MeBmt. Journal of the American Chemical Society, 108, 6757-6761. http://dx.doi.org/10.1021/ja00281a049

[30] Enders, D. and Shilvock, J.P. (2000) Some Recent Applications of $\alpha$-Amino Nitrile Chemistry. Chemical Society Reviews, 29, 359-373. http://dx.doi.org/10.1039/a908290e

[31] Ammar, J.A. (2012) IOSR-JAC, 3, 5-10.

[32] Al-Amery, M. (2012) JNUS, 15, 55-61.

[33] Cooper, J.W. (1980) Spectroscopic Techniques for Organic Chemists. John Wiley and Sons Inc., New York.

[34] Laamari, R., Benzakour, J., Berrekis, F. and Villemin, A. (2010) Les Technologies de Laboratoir, 5, 18-25.

[35] Sliverstien, R.M. and Websters, X. (1998) Spectroscopic Identification of Organic Compound. 6th Edition, John Wiley and Sons Inc., New York.

[36] Marsh, J. (1988) Advanced Organic Chemistry. 3rd Edition, Wiley Eastem, New Delhi, 240.

[37] Arab, S.T. and Al-Thrknstan, A.M. (2004) Corrosion Inhibition of Steel in Phosphoric Acid by Phenacyldimethyl Sulfonium Bromide and Some of Its $p$-Substituted Derivatives. Portugaliae Electrochimica Acta, 24, 53-69. http://dx.doi.org/10.4152/pea.200601053

[38] Bereket, G., Yurt, A., VstumKandemir, S., Balaban, A. and Erk, B. (2004) 5th Advanced Batteries and Accumulators, 2004.

[39] Popova, A., Sokolova, E., Raicheva, S. and Christov, M. (2003) AC and DC Study of the Temperature Effect on Mild Steel Corrosion in Acid Media in the Presence of Benzimidazole Derivatives. Corrosion Science, 45, 33-38. 
http://dx.doi.org/10.1016/S0010-938X(02)00072-0

[40] El-Awady, A., El-Nabey, A., Aziz, S. and Electrochem, J. (1992) Kinetic-Thermodynamic and Adsorption Isotherms Analyses for the Inhibition of the Acid Corrosion of Steel by Cyclic and Open-Chain Amines. Journal of the Electrochemical Society, 139, 2149-2154. http://dx.doi.org/10.1149/1.2221193

[41] Bond, G.C. (1962) Catalysis by Metals. Academic Press, New York, 70-71, 126. 